\title{
A Rare Case of Acute-Onset Spastic Quadriparesis Caused by a Chondroma of the Cervical Spine
}

\author{
Kaori Momota, ${ }^{1,2}$ Toshihiko Nishisho $\mathbb{D}^{1},{ }^{1}$ Ryo Miyagi, ${ }^{1}$ Shunichi Toki $\mathbb{D},{ }^{1}$ \\ Kazuta Yamashita, ${ }^{1}$ Fumitake Tezuka, ${ }^{1}$ Yoichiro Takata ${ }^{D},{ }_{1}^{1}$ Toshinori Sakai ${ }^{D},{ }^{1}$ \\ Akihiro Nagamachi $\mathbb{D}^{2}{ }^{2}$ Toru Maeda, ${ }^{1}$ and Koichi Sairyo $\mathbb{D}^{1}$ \\ ${ }^{1}$ Department of Orthopedics, Institute of Biomedical Sciences, Tokushima University Graduate School, Tokushima, Japan \\ ${ }^{2}$ Department of Orthopedics, Takamatsu Municipal Hospital, Takamatsu, Japan
}

Correspondence should be addressed to Koichi Sairyo; sairyokun@hotmail.com

Received 8 February 2019; Revised 15 April 2019; Accepted 5 May 2019; Published 23 May 2019

Academic Editor: Akio Sakamoto

Copyright (C) 2019 Kaori Momota et al. This is an open access article distributed under the Creative Commons Attribution License, which permits unrestricted use, distribution, and reproduction in any medium, provided the original work is properly cited.

\begin{abstract}
Chondromas are benign cartilaginous tumors that occur very rarely in the spine. Moreover, chondromas of the extraskeletal origin are also very rare. In this case report, we describe an extremely rare case of chondroma arising from the ligamentum flavum in the cervical spine. A 67-year-old man presented to our clinic with acute-onset spastic quadriparesis. We performed emergent magnetic resonance imaging and found an epidural mass in the right ligamentum flavum at C4-C5. The acute-onset presentation was suspicious for intraligamentous hematoma in the ligamentum flavum at this level. We performed emergency decompression surgery and en bloc removal of the epidural mass with the right C4 and C5 lamina. The lesion had the appearance of cartilaginous tissue rather than hematoma. Based on the histological investigation, the final diagnosis was intraligamentous chondroma of the cervical spine. The quadriparesis improved postoperatively, as did the results of manual muscle testing in the affected area, and he was able to resume walking independently with a cane. At the one-year follow-up, the manual muscle testing results were almost normal. Surgeons should keep in mind the possibility of benign tumors including chondroma of the cervical spine when a patient presents with acute-onset quadriparesis.
\end{abstract}

\section{Introduction}

Soft-tissue chondroma is a benign mesenchymal neoplasm that contains cells with a chondrocyte phenotype, secretes cartilage matrix, and arises in extraosseous and extrasynovial tissues [1]. Although these tumors can arise at any age, most patients are middle-aged (mean, 34.5 years) [2, 3]. Twothirds of these tumors occur in the fingers [3-5], and the rest arise in the hands, followed by the toes and feet. Chondromas that originate in the trunk or the head and neck region [6] are uncommon, and those that have their origin in the spine are very rare. In 2015, Byun et al. reported a case of cervical chondroma and reviewed the literature [7], which at that time contained only 10 cases. More recently, in 2018, Inoue et al. reviewed chondroma in the cervical region and identified 16 cases [8]. In most cases, the lesion was found because of paresis.
Most chondromas are solitary and present as a painless mass in the soft tissue around tendons and joints. Chondromas arising from ligamentous tissue are rare, with only one case report involving the knee reported in the literature [9]. In this report, we describe a patient who presented with acute-onset spastic quadriparesis and was found to have a chondroma in the cervical region that was compressing the spinal cord. The tumor was located in the ligamentum flavum in the cervical spine, which is apparently quite rare. This study was approved by the Ethics Committee of Tokushima University.

\section{Case Report}

A 67-year-old man presented to our clinic with acute-onset spastic quadriparesis. During the previous 2 years, he had been under follow-up at 3-month intervals in our clinic following decompressive laminectomy for lumbar spinal canal 
TABLE 1: Results of manual muscle testing.

\begin{tabular}{lcc}
\hline Muscles tested & Right & Left \\
\hline Deltoid & 4 & 4 \\
Biceps & 3 & 5 \\
Brachioradialis & 3 & 5 \\
Triceps & $3-$ & 5 \\
Carpal flexors & 2 & 5 \\
Iliopsoas & 3 & 4 \\
Quadriceps & 4 & 4 \\
Tibialis anterior & $2-$ & 4 \\
\hline
\end{tabular}

stenosis and fusion surgery for ossification of the ligamentum flavum of the thoracic spine. In April 2016, he suddenly noticed quadriparesis. He could not stand or walk, but did not present to our clinic until his scheduled follow-up visit 2 weeks later. Manual muscle testing (MMT) confirmed right-dominant quadriparesis (Table 1). Patellar and Achilles tendon reflexes were hypoactive, suggesting likely spinal canal stenosis and ossification of the ligamentum flavum. He had a spastic, broad-based steppage gait and needed a walker for ambulation.

Emergent magnetic resonance imaging (MRI) revealed an epidural mass in the right ligamentum flavum at the $\mathrm{C} 4$ C5 level (Figures 1(a)-1(d)). The mass was isointense in T1WI and low to isointensity in T2WI. Computed tomography (CT) scanning confirmed that there was no ossification in the mass (Figures 1(e) and 1(f)). Given the acute and rapidly deteriorating clinical presentation, we thought this case was intraligamentous hematoma in the ligamentum flavum in the cervical spine. However, cervical MRI scan that had been acquired 2 years earlier to investigate neck pain (Figures $1(\mathrm{~g})$ and $1(\mathrm{~h})$ ) revealed that the tumor was present at that time but was smaller and not compressing the spinal cord. Therefore, the differential diagnosis was soft tissue tumor as well as hematoma. We performed emergency decompression surgery with removal of the epidural lesion. We removed the mass en bloc along with the right $\mathrm{C} 4$ and C5 lamina (Figure 2). The mass was $10 \mathrm{~mm} \times 10 \mathrm{~mm}$ in size, and there was an appearance of cartilaginous tissue rather than a hematoma (Figures 2(a) and 2(b)). Decompression of the dura mater was confirmed intraoperatively after the removal of the mass. Hematoxylin-eosin staining showed cartilaginous tissue, there were no atypical cells, and the final diagnosis was chondromatous lesion (Figure 2(c)). The mass presented 2 years before, and we made a diagnosis of intraligamentous chondroma of the cervical spine. Postoperatively, the quadriparesis and MMT results improved, and he was able to resume walking. At the one-year follow-up, the patient's MMT results were almost normal and he could walk independently with a cane. No recurrence was observed on follow-up MRI (Figure 3).

\section{Discussion}

Soft tissue (extraskeletal) chondroma is a rare benign tumor. We searched "extraskeletal chondroma" in PubMed and

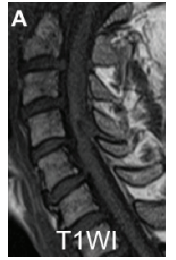

(a)

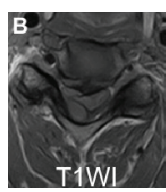

(b)

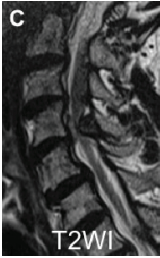

(c)

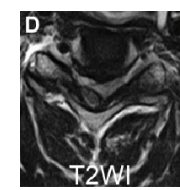

(d)

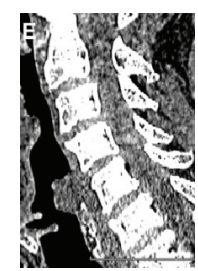

(e)

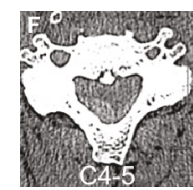

(f)

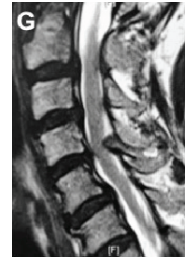

(g)

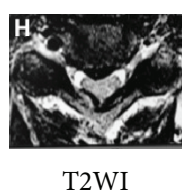

(h)
FIgURE 1: Magnetic resonance images (MRIs) and computed tomography scans (CTs) acquired at the time of acute onset of quadriparesis (a-f) and MRIs acquired 2 years earlier the quadriparesis (g, h): (a) sagittal T1WI, (b) axial T1WI, (c) sagittal T2WI, (d) axial T2WI, (e) sagittal CT, (f) axial CT, (g) sagittal T2WI, and (h) axial T2WI. Images at the onset shows a mass in the spinal canal at C4-5 on the right that is compressing the spinal cord. CT indicates that the mass did not contain osseous tissue. On the other hand, MRIs acquired 2 years earlier to investigate neck pain show that the tumor was present at that time but was not large or compressing the spinal cord.

there are 42 English papers. The location was various, hand and forearm [10-24], foot [25-31], head and neck [6, 3237], knee [38-42], gynecologic area [43, 44], axilla [45], abdominal wall [46], and gluteal region [47]. The most common location is the hand and forearm. This tumor is thought to arise from the fibrous stroma of soft tissues rather than originating from mature cartilaginous or osseous tissue. Extraskeletal chondroma typically affects adults, usually between the ages of 30 and 60 years [27, 45].

We have described a very rare case of chondroma in the ligamentum flavum at the level of the cervical spine. A literature search in 2018 by Inoue et al. [8] identified 16 cases of chondroma in the cervical spine region, implying that our case is the 17th to be reported. Moreover, in our patient, the tumor was in the ligamentum flavum at the C4-C5 level. As mentioned earlier, there has only been 1 report of a chondroma arising in ligamentous tissue and involving the knee joint [9]. Therefore, a chondroma in the cervical ligamentum flavum would be rare indeed, and this case could be the first report.

In our patient, the symptoms had an acute onset and the tumor was located in the ligamentum flavum. We initially suspected that the mass was an intraligamentous hematoma. Tamura et al. [48] had previously reported a case of acuteonset quadriparesis caused by intraligamentous hematoma in the cervical spine. The clinical presentation in our patient was similar to that in their case, and there was no reason to suspect a tumor as the cause of his acute-onset quadriparesis. The tumor 2 years earlier was small and did not compress the spinal cord. The tumor had gradually increased in size in the intervening 2 years. Surgeons should be aware that patients with slow-growing benign tumors like chondroma could present with acute-onset quadriparesis. 


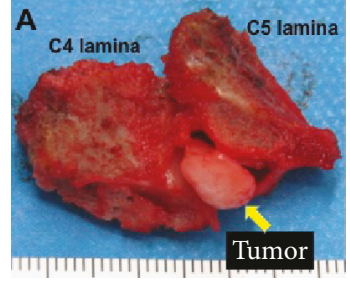

(a)

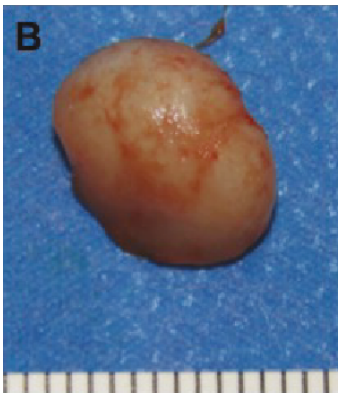

(b)

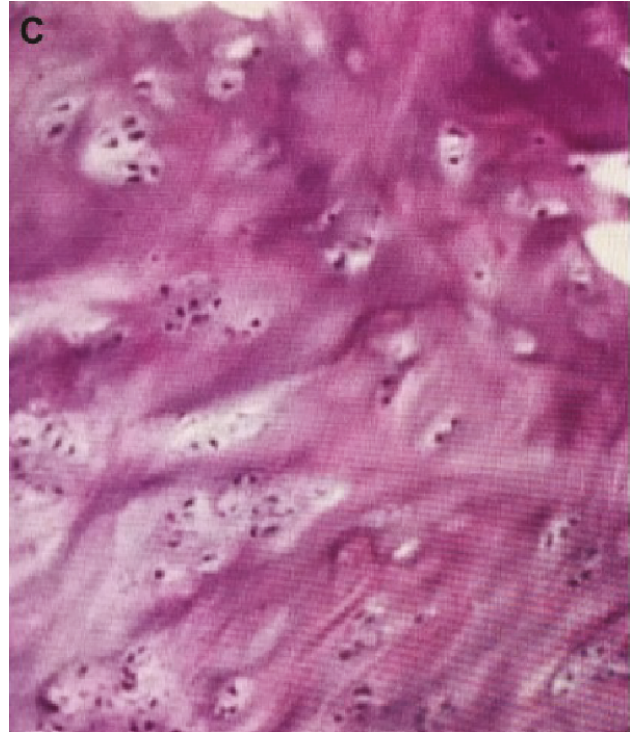

(c)

Figure 2: (a, b) Macroscopic features of the tumor specimen with the cervical lamina (the smallest division of the scale is $1 \mathrm{~mm}$ ). (c) Histological findings from the resected tumor revealed cartilaginous tissue with no atypical cells (hematoxylin-eosin staining).

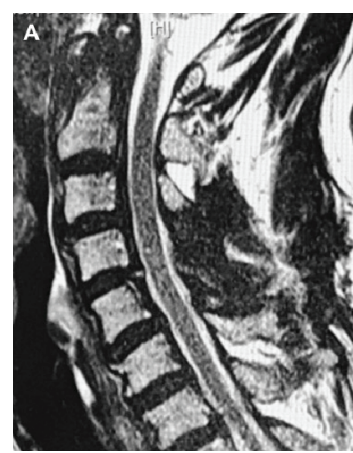

(a)

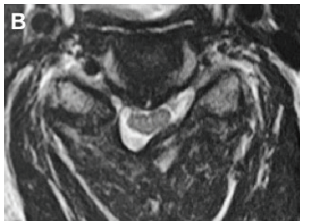

C4-5

(b)

FIgURe 3: Postoperative MRIs confirm decompression of the cervical spinal cord. (a) Sagittal T2WI. (b) Axial T2WI.

It is unclear how chondroma can arise in a ligament or other soft tissue. It is well known that mesenchymal stem cells can differentiate to chondrocytes in vitro $[49,50]$. Therefore, chondroma may arise from mesenchymal stem cells via some form of tumorigenesis [51]. Ligaments also contain mesenchymal stem cells, but the number is small and their clinical significance remains unclear [6]. This may explain why chondromas arising in ligamentous tissue are so rare.

\section{Conflicts of Interest}

The authors have no conflicts of interest to declare.

\section{Acknowledgments}

We are grateful to Dr. Yoshimi Bando (Division of Pathology, Tokushima University Hospital, Tokushima, Japan) for contributions to confirming the pathological diagnosis in this case.

\section{References}

[1] C. D. M. Fletcher and World Health Organization, International Agency for Research on Cancer, WHO Classification of Tumours of Soft Tissue and Bone, IARC Press, Lyon, 4th edition, 2013.

[2] E. B. Chung and F. M. Enzinger, "Chondroma of soft parts," Cancer, vol. 41, no. 4, pp. 1414-1424, 1978.

[3] L. Pollock, M. Malone, and D. G. Shaw, "Childhood soft tissue chondroma: a case report," Pediatric pathology \& laboratory medicine, vol. 15, no. 3, pp. 437-441, 1995.

[4] S. Humphreys, H. Pambakian, P. H. McKee, and C. D. Fletcher, "Soft tissue chondroma-a study of 15 tumours," Histopathology, vol. 10, no. 2, pp. 147-159, 1986.

[5] A. Khedhaier, R. Maalla, K. Ennouri, and N. Regaya, "Soft tissues chondromas of the hand: a report of five cases," Acta orthopaedica Belgica, vol. 73, no. 4, pp. 458-461, 2007.

[6] J. Falleti, R. De Cecio, A. Mentone et al., "Extraskeletal chondroma of the masseter muscle: a case report with review of 
the literature," International journal of oral and maxillofacial surgery, vol. 38, no. 8, pp. 895-899, 2009.

[7] Y. H. Byun, S. Sohn, S. H. Park, and C. K. Chung, "Cervical spine chondroma compressing spinal cord: a case report and literature review," Korean Journal of Spine, vol. 12, no. 4, pp. 275-278, 2015.

[8] T. Inoue, Y. Ohara, T. Niiro, T. Endo, T. Tominaga, and J. I. Mizuno, "Cervical periosteal chondroma causing spinal cord or nerve compression: 2 case reports and literature review," World Neurosurgery, vol. 114, pp. 99-105, 2018.

[9] R. Sutera, A. Contiguglia, A. Iovane, and M. Midiri, "A rare case of enchondromatosis of the knees and hands with involvement of Hoffa's fat pad and peri-articular soft-tissues," Journal of radiology case reports, vol. 7, no. 6, pp. 22-30, 2013.

[10] J. K. Chan, K. C. Lee, and D. Saw, "Extraskeletal chondroma with lipoblast-like cells," Human Pathology, vol. 17, no. 12, pp. 1285-1287, 1986.

[11] G. Perri and D. Tripi, “Case report 393," Skeletal Radiology, vol. 15, no. 7, pp. 575-577, 1986.

[12] J. L. DelSignore, B. A. Torre, and R. J. Miller, "Extraskeletal chondroma of the hand. Case report and review of the literature," Clinical Orthopaedics and Related Research, vol. 254, pp. 147-152, 1990.

[13] R. E. Van Demark Sr., R. E. Van Demark Jr., and L. Hogrefe, "Hand tumors: extraskeletal chondroma and osteoma-case reports," South Dakota Journal of Medicine, vol. 43, no. 2, pp. 5-7, 1990.

[14] T. Isayama, H. Iwasaki, and M. Kikuchi, "Chondroblastomalike extraskeletal chondroma," Clinical Orthopardics and Related Research, vol. 268, pp. 214-217, 1991.

[15] T. Yamada, T. Irisa, S. Nakano, and O. Tokunaga, "Extraskeletal chondroma with chondroblastic and granuloma-like elements," Clinical Orthopaedics and Related Research, vol. 315, pp. 257-261, 1995.

[16] D. Cumming, A. Massraf, and J. W. Jones, "Extraskeletal chondroma as a cause of carpal tunnel syndrome: a case report," Hand Surgery, vol. 10, no. 02n03, pp. 327-330, 2005.

[17] P. Singh, S. K. Mathur, Z. S. Kundu, S. Singh, N. Marwah, and B. Arora, "Extraskeletal chondroma of the hand-a case report," Indian journal of pathology \& microbiology, vol. 48, no. 2, pp. 206-208, 2005.

[18] T. Ishii, M. Ikeda, and Y. Oka, "Subungual extraskeletal chondroma with finger nail deformity: case report," The Journal of Hand Surgery, vol. 35, no. 2, pp. 296-299, 2010.

[19] S. Suganuma, K. Tada, and H. Tsuchiya, "Giant extraskeletal chondroma of the index finger: a case report," Journal of Plastic, Reconstructive \& Aesthetic Surgery, vol. 64, no. 10, pp. 1377-1379, 2011.

[20] K. Ikeda, N. Osamura, and S. Kasashima, "A large extraskeletal chondroma in the hand of an elderly patient - a case report," Hand Surgery, vol. 18, no. 1, pp. 111-114, 2013.

[21] M. Saito, K. Nishimoto, R. Nakayama et al., "Extraskeletal chondroma of the index finger: a case report," Case Reports in Oncology, vol. 10, no. 2, pp. 479-484, 2017.

[22] K. Schwaiger, F. Ensat, D. Neureiter, G. Wechselberger, and M. Hladik, "Trigger finger caused by extraskeletal chondroma," The Journal of Hand Surgery, vol. 42, no. 1, pp. e51e55, 2017.

[23] R. Wenny, M. S. Pollhammer, D. Duscher et al., "Giant extraskeletal chondroma of the hand: a rare case," Archives of Plastic Surgery, vol. 45, no. 4, pp. 388-389, 2018.
[24] T. Le Corroller, C. Bouvier-Labit, and P. Champsaur, "Diffuse mineralization of forearm extraskeletal chondroma," Joint Bone Spine, vol. 75, no. 4, pp. 479-481, 2008.

[25] M. J. O'Malley, G. T. Faller, and C. C. Craig, "Extraskeletal chondroma of the foot," Orthopedics, vol. 19, no. 3, pp. 256258, 1996.

[26] D. S. Williams and S. Zichichi, "Extraskeletal chondroma of the foot," Journal of the American Podiatric Medical Association, vol. 88, no. 10, pp. 506-509, 1998.

[27] P. J. Papagelopoulos, O. D. Savvidou, A. F. Mavrogenis, G. D. Chloros, K. T. Papaparaskeva, and P. N. Soucacos, "Extraskeletal chondroma of the foot," Joint Bone Spine, vol. 74, no. 3, pp. 285-288, 2007.

[28] V. Rajalakshmi, V. A. Jayaraman, and N. Ramprasad, "Extraskeletal Chondroma of the Foot-A Case Report," Journal of Clinical and Diagnostic Research, vol. 8, no. 3, pp. 134-135, 2014.

[29] T. Vaseenon, C. Cheewawattanachai, N. Pattamapaspong, J. Settakorn, and T. Leerapun, "Extraskeletal chondroma on the sole of the foot," Foot \& Ankle Specialist, vol. 7, no. 3, pp. 232-236, 2014.

[30] D. Alaseirlis, I. Tsifountoudis, G. Konstantinidis, D. Miliaras, N. Malliaropoulos, and P. Givissis, "Para-articular extraskeletal chondroma mimicking first metatarsophalangeal synovitis," Radiology Case Reports, vol. 12, no. 3, pp. 564-570, 2017.

[31] D. Prins and L. Fuchs, "Extraskeletal chondroma with concomitant arthrosis of the foot at the first metatarsophalangeal joint: a case report," Journal of the American Podiatric Medical Association, vol. 107, no. 6, pp. 561-564, 2017.

[32] M. B. Aslam and M. T. Haqqani, "Extraskeletal chondroma of parotid gland," Histopathology, vol. 48, no. 4, pp. 465-467, 2006.

[33] H. Kwon, H. Y. Kim, S. N. Jung, W. I. Sohn, and G. Yoo, "Extraskeletal chondroma in the auricle," Journal of Craniofacial Surgery, vol. 21, no. 6, pp. 1990-1991, 2010.

[34] F. Watanabe, T. Saiki, and Y. Ochochi, "Extraskeletal chondroma of the preauricular region: a case report and literature review," Case Reports in Medicine, vol. 2012, Article ID 121743, 4 pages, 2012.

[35] Y. Choi, W. S. Lim, A. Y. Lee, and S. H. Lee, "Extraskeletal chondroma of the scalp: an atypical location," Indian Journal of Dermatology, Venereology, and Leprology, vol. 79, no. 3, pp. 435-436, 2013.

[36] H. Temsamani, A. Mouhsine, I. Benchafai, and F. Benariba, "Bilateral extraskeletal chondroma of the neck," European Annals of Otorhinolaryngology, Head and Neck Diseases, vol. 133, no. 4, pp. 295-296, 2016.

[37] H. Holtmann, T. Ruggeberg, C. K. Sproll et al., "Extraskeletal chondroma walling the temporomandibular joint: report of a rare case and review of the literature," International Journal of Surgery Case Reports, vol. 49, pp. 67-69, 2018.

[38] O. Bostman, E. Karaharju, L. Heikkonen, and T. Holmstrom, "Extraskeletal ossifying chondroma in the knee: A case report," Acta Orthopaedica Scandinavica, vol. 56, no. 1, pp. 87-89, 1985.

[39] I. Kudawara, T. Ueda, and N. Araki, "Extraskeletal chondroma around the knee," Clinical Radiology, vol. 56, no. 9, pp. 779$782,2001$.

[40] V. K. Singh, G. Shah, P. K. Singh, and D. Saran, "Extraskeletal ossifying chondroma in Hoffa's fat pad: an unusual cause of 
anterior knee pain," Singapore Medical Journal, vol. 50, no. 5, pp. e189-e192, 2009.

[41] A. P. Singh, I. K. Dhammi, A. K. Jain, and S. Bhatt, "Extraskeletal juxtaarticular chondroma of the knee," Acta Orthopaedica et Traumatologica Turcica, vol. 45, no. 2, pp. 130-134, 2011.

[42] B. Y. Mao, "Extraskeletal chondroma in the popliteal region: a case report," Chinese Medical Sciences Journal, vol. 30, no. 4, pp. 270-272, 2015.

[43] J. Y. Han, H. S. Han, Y. B. Kim, J. M. Kim, and Y. C. Chu, "Extraskeletal chondroma of the fallopian tube," Journal of Korean Medical Science, vol. 17, no. 2, pp. 276-278, 2002.

[44] M. Varras, C. Akrivis, G. Tsoukalos, C. Plis, S. Karadaglis, and I. Ladopoulos, "Tubal ectopic pregnancy associated with an extraskeletal chondroma of the fallopian tube: case report," Clinical and Experimental Obstetrics and Gynecology, vol. 35, no. 1, pp. 83-85, 2008.

[45] I. Adaletli, T. Laor, H. Yin, and D. J. Podberesky, "Extraskeletal chondroma: another diagnostic possibility for a soft tissue axillary mass in an adolescent," Case Reports in Orthopedics, vol. 2011, Article ID 309328, 4 pages, 2011.

[46] P. Goyal, S. Sehgal, S. Ghosh, D. Mittal, and S. Singh, "Extraskeletal chondroma of anterior abdominal wall in a child," APSP Journal of Case Reports, vol. 4, no. 3, p. 54, 2013.

[47] A. Parihar, N. P. Khan, and V. Agrawal, "Extraskeletal chondroma of the gluteal region along with sporadic neurofibroma - an unusual presentation," Journal of Clinical and Diagnostic Research, vol. 9, no. 5, pp. ED07-ED08, 2015.

[48] T. Tamura, T. Sakai, K. Sairyo et al., "Hematoma in the cervical ligamentum flavum. Report of a case and review of the literature," Skeletal Radiology, vol. 39, no. 3, pp. 289-293, 2010.

[49] A. E. Denker, A. R. Haas, S. B. Nicoll, and R. S. Tuan, "Chondrogenic differentiation of murine C3H10T1/2 multipotential mesenchymal cells: I. Stimulation by bone morphogenetic protein-2 in high-density micromass cultures," Differentiation, vol. 64, no. 2, pp. 67-76, 1999.

[50] A. R. Haas and R. S. Tuan, "Chondrogenic differentiation of murine C3H10T1/2 multipotential mesenchymal cells: II. Stimulation by bone morphogenetic protein-2 requires modulation of N-cadherin expression and function," Differentiation, vol. 64, no. 2, pp. 77-89, 1999.

[51] M. Bansal, A. B. Goldman, E. F. DiCarlo, and R. McCormack, "Soft tissue chondromas: diagnosis and differential diagnosis," Skeletal Radiology, vol. 22, no. 5, pp. 309-315, 1993. 


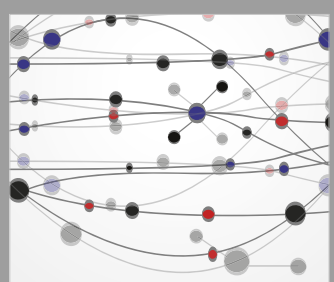

The Scientific World Journal
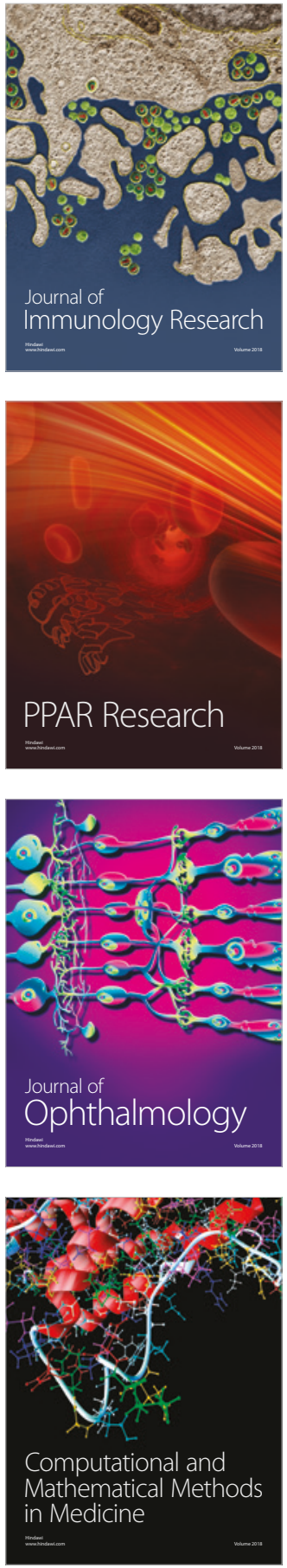

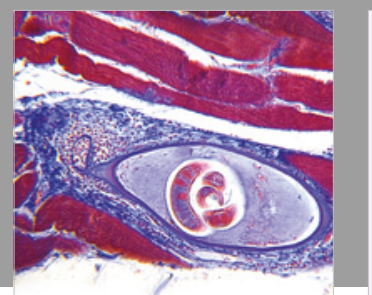

Gastroenterology Research and Practice

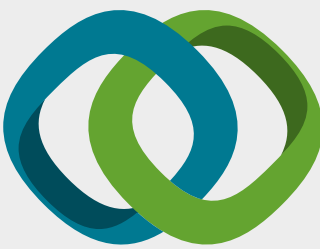

\section{Hindawi}

Submit your manuscripts at

www.hindawi.com
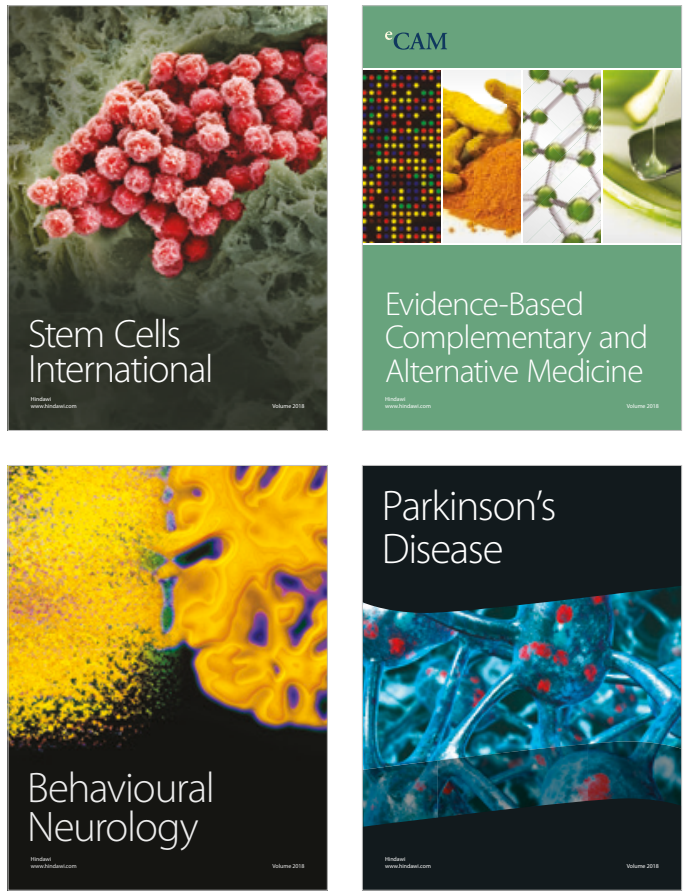

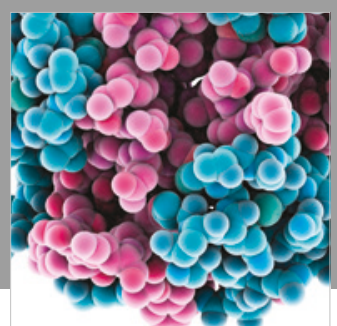

ournal of

Diabetes Research

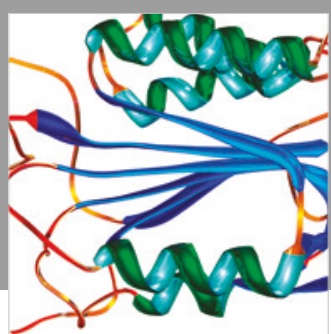

Disease Markers
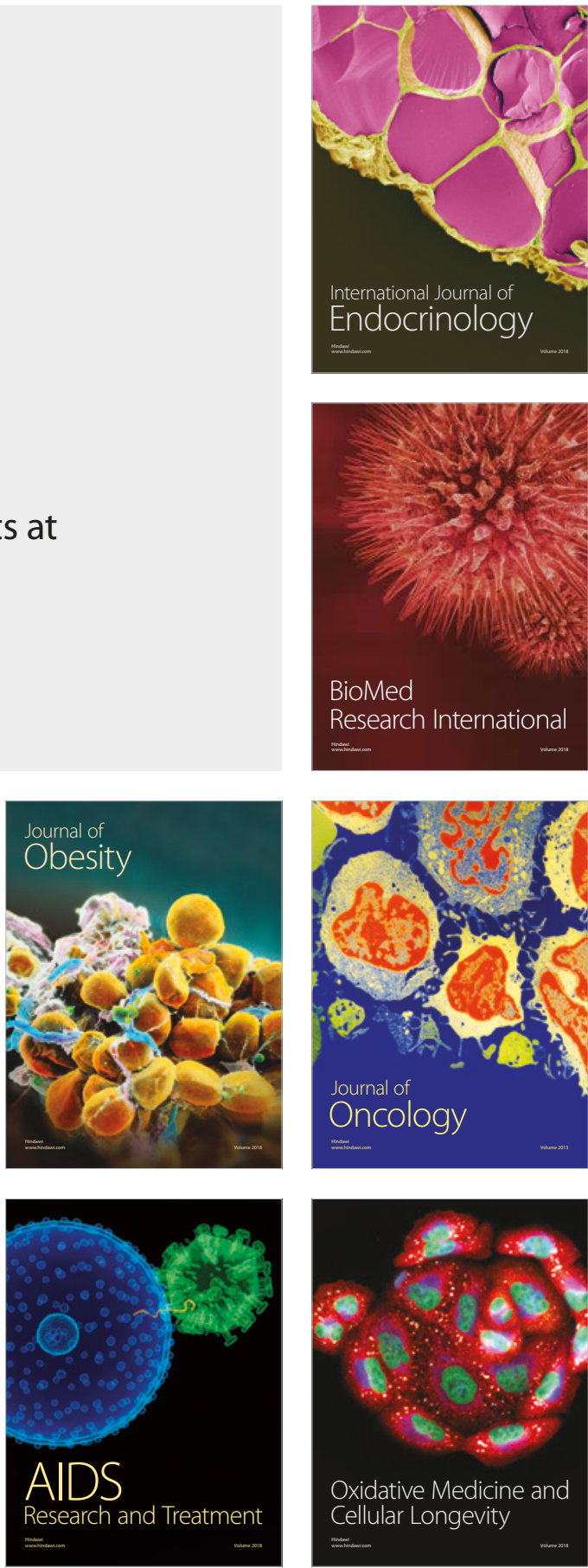